\title{
En dinosaur ved Århus Domkirke - fodspor fra en svunden tid
}

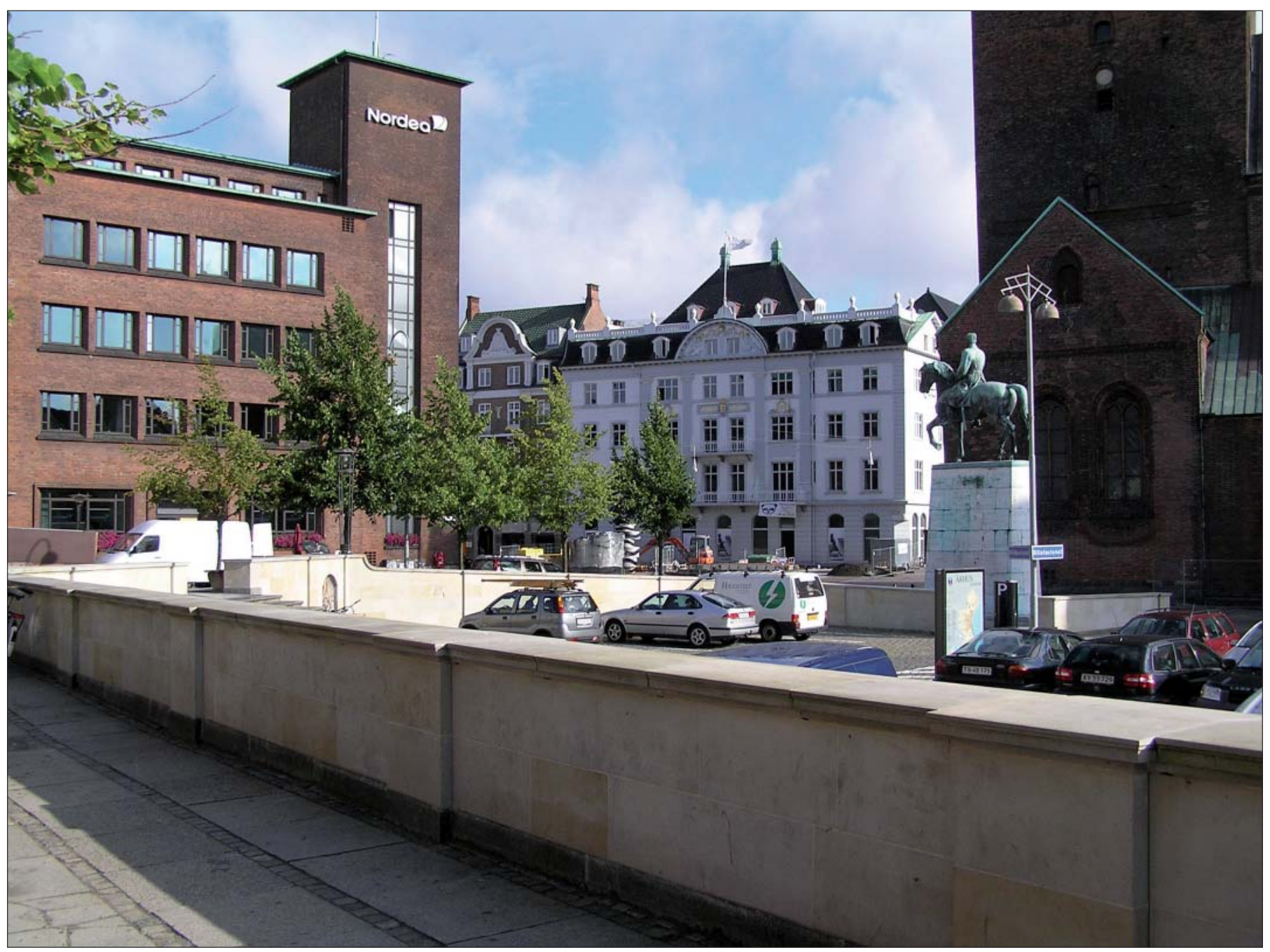

Billede af Bispetorvet ved Århus Domkirke med den nyrestaurerede sandstensmur. Dinosaursporet er indmuret $i$ veggen foran den grå bil med stigen på taget. (Foto: Alice Rosborg)

Af Jesper Milàn, Institut for Geografi og Geologi, Københavns Universitet \& Alice Rosborg, Århus Kommune - Teknik og Miljø Planlcegning og Byggeri, Byarkitektur, Rådhuset

Fra sommeren 2007 har Århus midtby fået en helt speciel seværdighed. Der er nemlig blevet muret et forstenet fodaftryk af en rovdinosaur ind i Bispetorvets vestvæg. Der er tale om en sandsten fra Kridttiden, og aftrykket er mellem 140 og 120 millioner år gammelt.
I sommeren 2007 fik Århus en ny turistattraktion, der er lidt ud over det sædvanlige, nemlig et forstenet fodspor fra en 140-120 millioner år gammel dinosaur indmuret i Bispetorvets vestvæg omkring halvtreds meter fra Århus Domkirke.

\section{Bispetorvet}

Historien, om hvordan det forstenede dinosaurfodspor fandt sin vej dertil, tager sin begyndelse tilbage i 2005, da Århus Byråd besluttede at bevillige penge til restaurering af sandstensmuren, der omslutter Bispetorvet (foto ovenfor).

I 1921 fik Bispetorvet den udformning, som vi kender i dag, efter en konkurrence, som arkitekterne Th. Havning og H. Mundt vandt og senere fik mulighed for delvist at realisere. Bygningsværket blev opmuret i gule teglsten, beklædt og afdækket med Cotta-sandsten fra området nær Dresden. Års slid havde gennem tiden sat sit præg på muren - at ældes med ynde - holdt ikke mere, det var tid til en restaurering. Det besluttedes i løbet af processen, at enkelte af de oprindelige sandsten skulle bevares og samles på et sted i muren, og ellers skulle resten fornyes. Med konservator Leif Vognsen som rådgiver besluttedes det at benytte sandsten fra stenbruddene ved Obernkirchen i Tyskland også kaldet Bremer Sandsten. Denne har et fantastisk farve- 
spil fra det sarte lysegule til okker og brunt. Som afdækning benyttedes en grå, stærkere sandsten også fra Obernkirchen.

Som del af godkendelse og kvalitetsproceduren var et besøg i stenbruddet nødvendigt for at inspicere sandstenen. I skærehallen stod en palle med fliser, der ikke kunne bruges, da de indeholdt forskellige forsteninger (se de to fotos på denne side). Blandt disse forsteninger var blandt andet et stort, flot dinosaurfodspor, og her opstod ønsket om at få sådan et spor til at mure ind i væggen. Som sagt så gjort, og i efteråret 2006 blev dinosaurerfodsporet så leveret i Århus, hvorefter det omhyggeligt blev fastgjort på en prominent plads i vestvæggen tæt ved Domkirken. Efterfølgende er indmuret en sandstensplade med en orienterende tekst ved siden af sporet (foto øverst på næste side).

\section{Dinosaursporet}

Den lyse sandsten, der brydes ved Obernkirchen, er omkring 120 millioner år gammel og fra begyndelsen af Kridttiden. I Kridttiden, da sandstenen blev aflejret, var området et kystnært flodslettemiljø, og selve sandstensformationen er blevet tolket som værende aflejret som store sandbanker ud fra flodmundingerne i tidevandszonen. Gennem årene er der blevet fundet adskillige velbevarede fossile fodspor fra dinosaurer i disse sandstensaflejringer. Langt den største mængde af forstenede fodspor, man kender

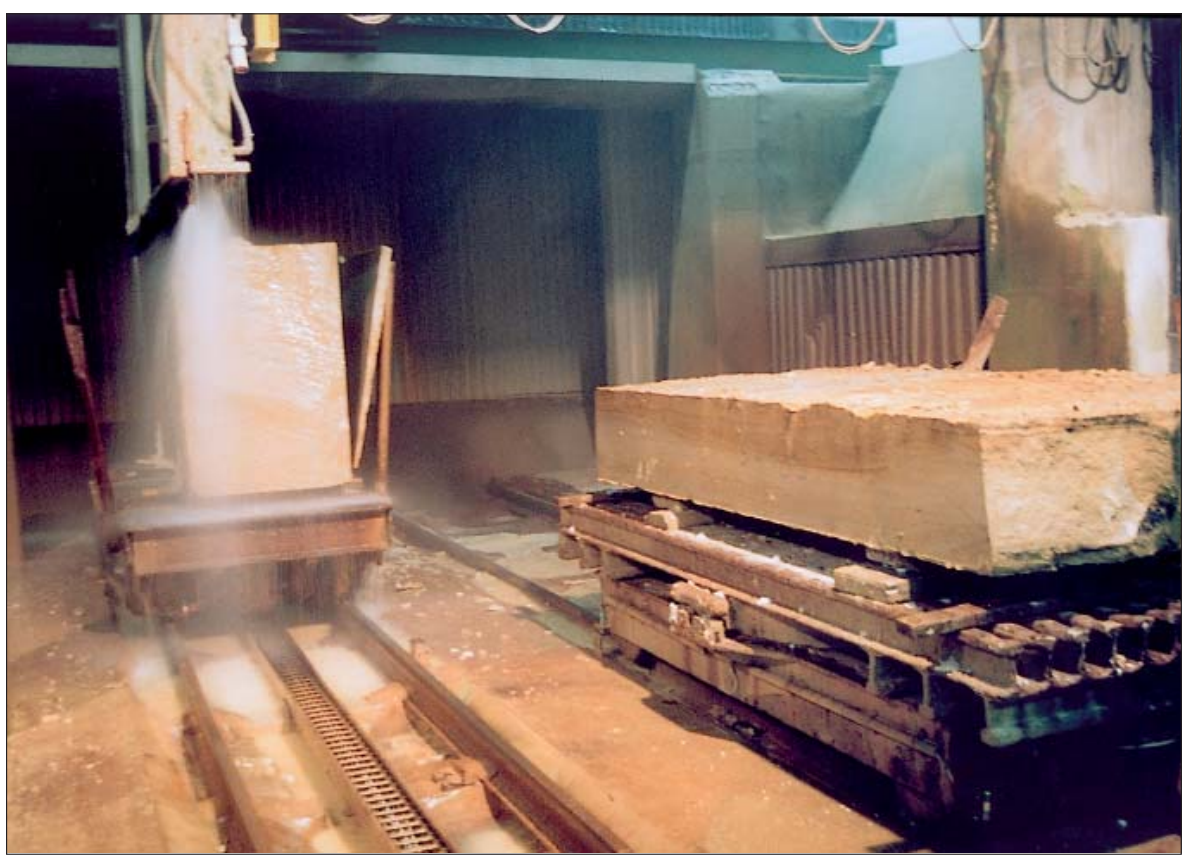

Skcrehallen i stenbruddet ved Obernkirchen. Her bliver den gullige sandsten skåret ud til fliser med enorme vandkølede båndsave. (Foto: Alice Rosborg)

fra det område, er blevet sat af ornithopode dinosaurer. Ornithopoderne var en meget udbredt gruppe af planteædende dinosaurer, hvor Iguanodon er en af de bedst kendte former. Ornithopoderne havde brede fødder med tre korte tykke tæer og en massiv afrundet hæl. I mellem alle sporene fra de planteædende dinosaure findes af og til også sporene fra kødædende dinosaurer. Rovdinosaurernes spor er også tretåede og kan ved første øjekast godt forveksles med sporene fra de planteædende ornithopoder, men ved nærmere eftersyn er der en række tydelige forskelle. Sporene fra de planteædende

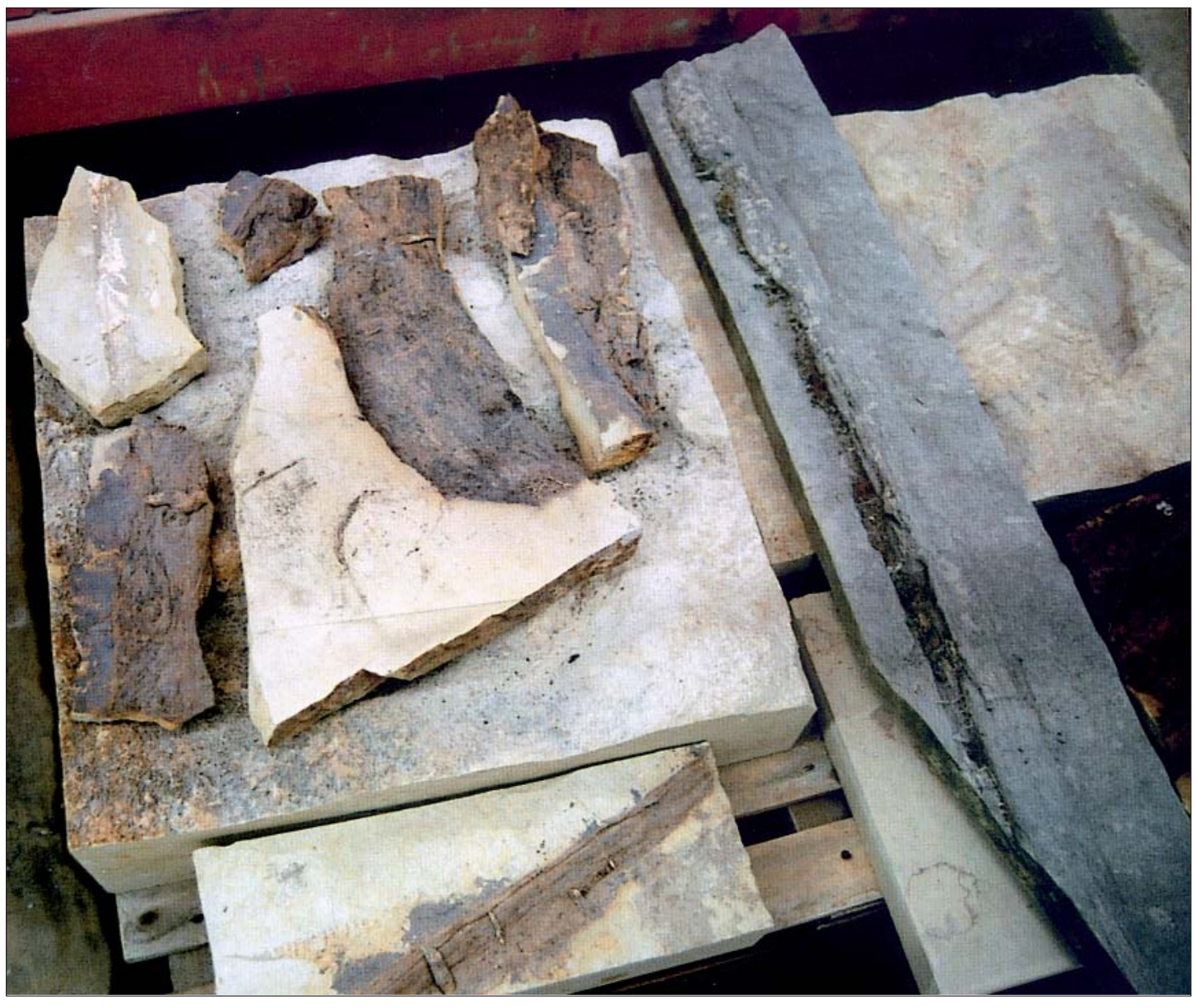

Sandstensplader, der indeholder fossiler, bliver sorteret fra, da de ikke kan anvendes til fliser. Her ses en palle med forskellige forstenede planter og oppe i højre hjørne en flise med et dinosaurspor. (Foto: Alice Rosborg) 


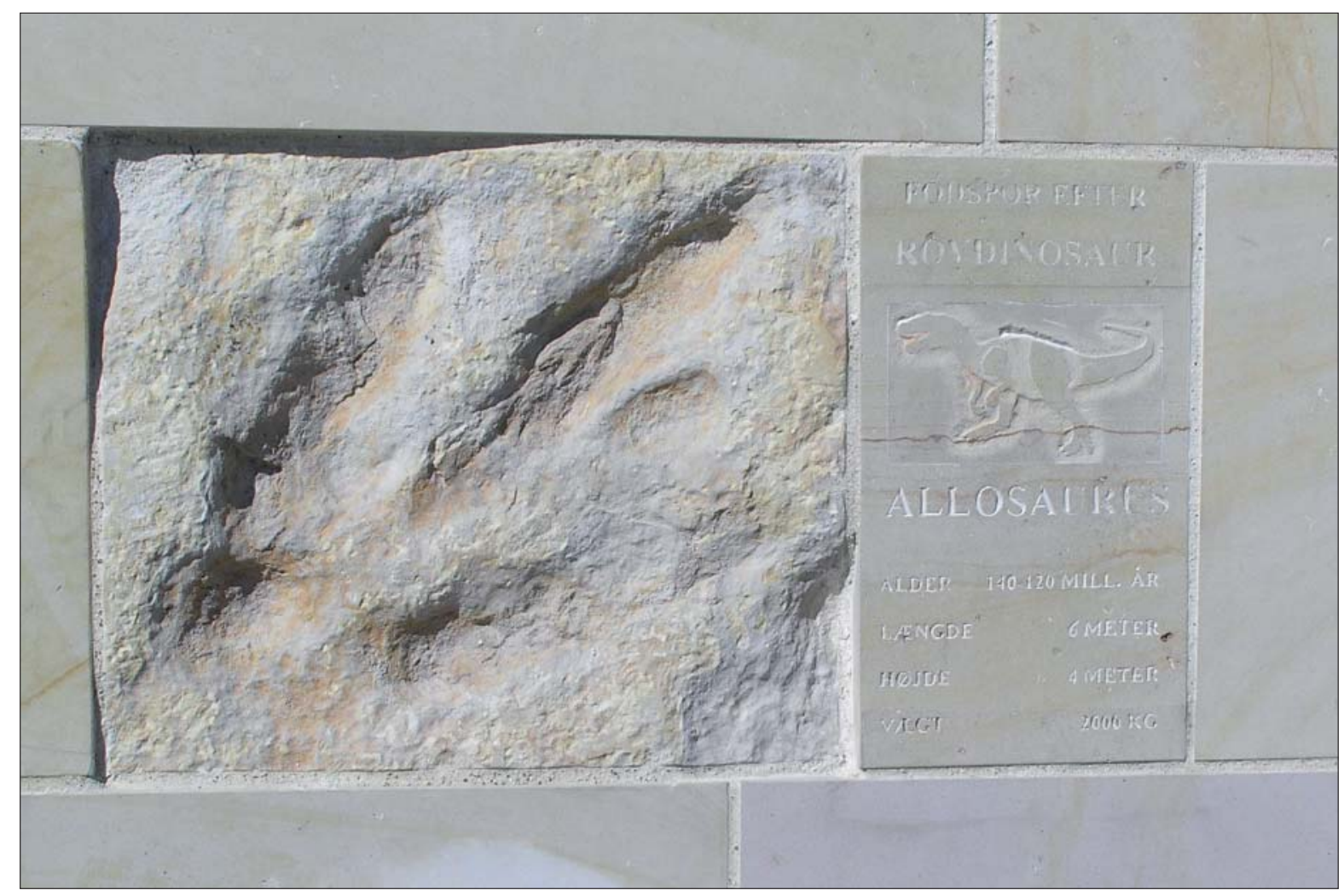

Dinosaurfodsporet er blevet indmuret i den nyrestaurerede sandstensvceg ud mod Bispetorvet. Ved siden af sporet er indmuret en lille forklarende tavle. (Foto:

Alice Rosborg)

ornithopoder er som hovedregel bredere, end de er lange og tæerne er korte og tykke og har kun aftryk af korte afrundede kløer.

Rovdinosaurernes spor derimod er længere, end de er brede, og aftrykkene af deres tæer er lange og slanke og har aftryk af lange skarpe kløer (illustrationen nedenfor til højre). I heldige tilfælde, hvor sporene er så godt bevaret som tilfældet med sporet ved Århus Domkirke, kan man endda se aftrykkene fra de enkelte trædepuder under hver enkelt af dinosaurens tæer. Trædepuderne hos fugle og rovdinosaurer er udviklet omkring leddene mellem de enkelte tåknogler (figuren på næste side).

Hos de planteædende ornithopoder er denne opdeling meget svær at erkende, da deres tæer er så korte og tykke, at de kun har en bred trædepude under hver tå. Antallet af knogler i tæerne hos rovdinosaurer er forskelligt fra tå til tå. Den inderste tå i foden har tre tåknogler, den midterste har fire og den yderste har fem. Den yderste tå går længere tilbage end de to andre og danner en lille asymmetrisk hælpude i fodsporet. Desuden har rovdinosaurern en fjerde lille tå, der sidder oppe på mellemfoden, og som ikke kommer i kontakt med jorden under normal gang. Det er denne tå, der hos dinosaurernes nulevende slægtninge, fuglene, er blevet bagudrettet og bruges til at gribe om grene med. Så ved at tælle aftrykkene af trædepuderne kan man beregne antallet at knogler i de enkelte tæer og derved bestemme, om fodsporet er fra en højre eller venstre fod.

Sporet ved Århus Domkirke er længere, end det er bredt, og aftrykkene af tæerne er lange og slanke og har tydelige mærker fra spidse kløer, og man kan også svagt se de enkelte trædepuder på tæerne. Desuden kan det ses, at den venstre tå i sporet går længere tilbage end de to andre og danner en asymmetrisk hæl (fotoet nederst på foregående side), og derved kan man se, at sporet stammer fra dinosaurens venstre fod. Sporet er 42 centimeter langt og med den oplysning, er det muligt at beregne omtrent, hvor høj dinosauren har været over hofterne.

Ved at måle proportionerne på benene og fødderne af forskellige typer rovdinosaurer, har man fundet ud af, at hoftehøjden (målt til hofteleddet) hos en rovdinosaur i gennemsnit svarer til fire gange fodens længde.
Dermed har rovdinosauren, der satte sporet, målt omkring 170 centimeter over hoften og har kunnet have hovedet op i 4 meters højde, når den rettede sig op. Den anslåede totale længde fra hoved til halespids har været omkring 6 meter.

\section{Hvem satte sporet?}

På den tid, hvor sporene blev sat i starten af Kridttiden for 140-120 millioner år siden, eksisterede der i Europa en række mellemstore rovdinosaurer, der kunne have sat sporet. Dog er de relativt dårligt kendt, da der ikke er fundet særlig meget skeletmateriale fra den periode. I slutningen af den foregående tidsperiode, Juratiden for 150 millioner
De to typiske dinosaurtyper man kender spor fra ved Obernkirchen. Størstedelen af de spor, der kendes fra stenbruddene, stammer fra ornithopode dinosaurer som Iguanodon, mens spor fra rovdinosaurer er mere sjceldne. Sporene fra begge typer har tre tceer, men sporene fra ornithopoder er bredere, end de er lange, og tceerne er korte og tykke. Sporene fra rovdinosaurer, her en Allosaurus, er langere, end de er brede, har slanke tceer og aftryk af skarpe kløer. (Illustration: Jesper Milàn)

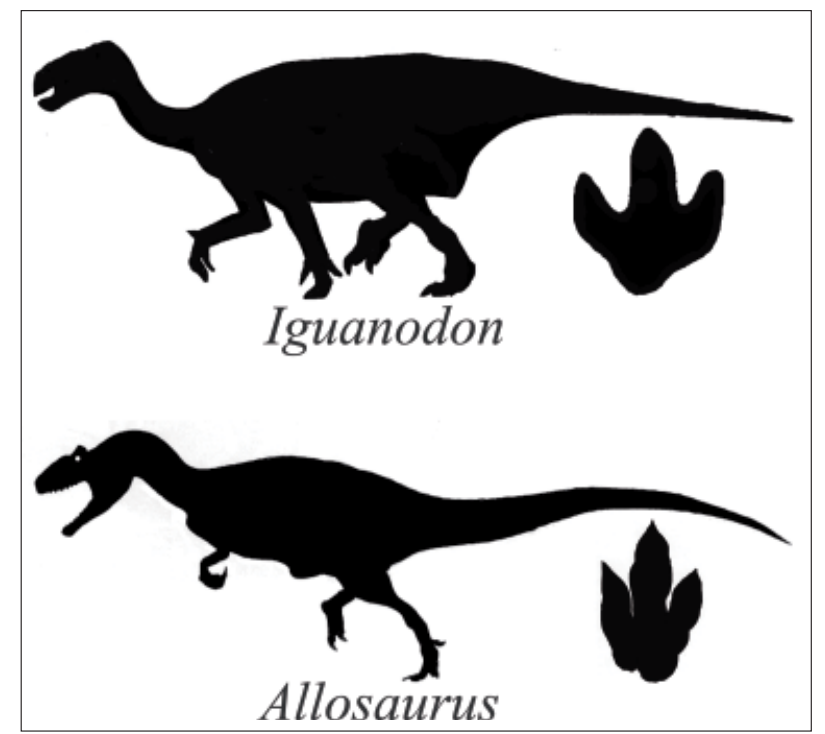


år siden, kendes velbevarede skeletter af adskillige store og mellemstore rovdinosaurer, som de kendte Allosaurus, Torvosaurus og Ceratosaurus. Disse former uddør dog ved grænsen til Kridttiden, men slægtninge til dem overlever op gennem Kridttiden, og det er blandt dem, at dinosauren, der satte sporet ved Obernkirchen, skal findes. Baseret på, hvad man kender af rovdinosaurskeletter fra begyndelse af Kridttiden i Tyskland og Nordeuropa, er det mest sandsynligt, at sporet er sat af et medlem af Allosaur-familien, altså en nær slægtning til den kendte Allosaurus fra Juratiden, men det eneste, der virkelig kan siges med sikkerhed om sporet, er, at det er fra en mellemstor rovdinosaur.

\section{Hvad kan man bruge spor til?}

Studiet af sporfossiler og især dinosaurspor har inden for de seneste 20 år haft en enorm renæssance, hvor store mængder af spor og sporserier fra hele verden er blevet beskrevet. Derudover er videnskaben også begyndt at få øjnene op for de muligheder, der ligger i studiet af fodspor. I tilfælde, hvor mange spor fra det samme dyr er bevaret som en sammenhængende sporserie, kan man bruge sporene til at bestemme, hvor hurtigt dyret har gået, og i tilfælde, hvor der findes spor fra mange dyr sammen, kan man ud fra sporene fortolke dyrenes adfærd. Fossile fodspor er så at sige meget mere end blot de forstenede aftryk fra det pågældende dyrs fod, de er i virkeligheden fastfrosne øjebliksbilleder af de enkelte dyrs liv og adfærd, da de satte sporene. Derved kan sporene være med til at bidrage med værdifuld anatomisk og adfærdsmæssig information, der ikke kan opnås ved at studere skeletter alene. Da sporet ved Århus Domkirke er et enkelt spor og ikke fundet i sammenhæng med en sporserie, kan man desværre ikke tolke mange adfærdsmæssige ting ud fra det. Men til gengæld kan folk i Århus glæde sig over en turistattraktion lidt ud over det sædvanlige. Det er trods alt ikke hver dag,
Skitse af et typisk fodspor fra en mellemstor rovdinosaur. Fodsporet er optegnet med lysegråt, og skelettet af den tilsvarende fod er optegnet med mørkegråt. Trcedepuderne på tceerne sidder rundt om leddene mellem de enkelte tåknogler ligesom hos moderne fugle. (Illustration: Jesper Milàn, modificeret fra original af R.S. Lull 1953)

man får mulighed for at as se og føle på et fodspor, der er over 120 mio. år gammelt og sat af en 6 meter lang rovdinosaur.

\section{Kort nyt}

\section{Vulkanudbrud i Yemen}

På den yemenitiske ø, Jabal al-Tair, i Det Røde Hav ca. 100 km ud for Yemens kyst omkom mindst otte soldater fra den yemenitiske hær, da en vulkan gik i udbrud sidst i september.

Den danske korvet Olfert Fischer, der patruljerer i området, deltog sammen med andre NATO-fartøjer i eftersøgningen af overlevende. 49 mennesker blev efter vulkanudbruddet evakueret fra øen. En talsmand for Yemens forsvarsministerium forklarede til pressen, at hele den vestlige del af øen kollapsede kort efter vulkanudbruddet.

AFP/SLJ

Engelske Kanal dannet af to flodbølger? Sonarbilleder antyder, at den Engelske Kanal blev dannet af to kæmpe flodbølger. Indtil for 450.000 år siden var England og Frankrig forbundet med en landtange - selv i tider med høj vandstand.

Da landtangen, der forbandt Nordafrika med den Iberiske halvø, brød sammen for ca. 6 millioner år siden, skabte den efterfølgende superflodbølge Gibraltarstrædet og fyldte Middelhavsbassinet i løbet af få årtier. Nogle geologer mener, at Bosporusstrædet ved Istanbul er dannet på lignende vis: Vand fra Middelhavet brød gennem landtangen mod Sortehavet og hævede vandstanden med sådan en hast, at samfundene langs Sortehavets kyster blev drevet på flugt. Oversvømmelsen kan være oprindelsen til fortællingen om Noahs ark.

På grundlag af en seismisk undersøgelse af bunden af den Engelske Kanal foreslog Alec Smith fra Royal Holloway College i 1985, at Doverstrædet, der forbinder den Engelske Kanal med Nordsøen, blev skabt for et par hundrede tusind år siden ved et pludseligt brud på kalk-højderyggen, som indtil da havde forbundet England med det nordvestlige Frankrig. Men de tilgængelige målinger kunne ikke afgøre, om kanalen var opstået pludseligt eller ved gradvis nedbrydning af landtangen som følge af is-erosion $\mathrm{i}$ istiderne, tidevandsslitage og flodernes erosion i tider med lavvande, når den Engelske kanal kun var et system af floder.

Men nu kan et hold ledet af Sanjeev Gupta of Jenny Collier fra Imperial College berette, at nye sonarbilleder taget med høj opløsning over adskillige tusinde kvadratki- lometre af den Engelske kanals bund giver stærke beviser for den katastrofale oversvømmelse foreslået af Alec Smith. Man har længe vidst, at den smalle kanalbund krydses af en lang undersøisk dal kaldet den Nordlige Palceodal. Den høje opløsning af de nye målinger viser, at dalen har dybe kanaler og furer skåret ind i grundfjeldet, strømlinede øer, fletningslignende forgreningsmønstre og vandfald, som tilsammen er vanskelige at forklare ved andet end rivende superoversvømmelser. Ligheden mellem de undersøiske former, og hvad man finder i Channeled Scablands i den østlige del af staten Washington, er slående, siger Gupta.

Det underlige landskab blev skåret ud for 15 tusinde år siden hen imod slutningen af den seneste istid af en superoversvømmelse forårsaget af et pludseligt sammenbrud af en høj isdæmning, som ind til da havde opstemmet den enorme Paleolake Missoula i det vestlige Montana. Da dæmningen brød sammen, fossede 10 millioner tons vand mod vest per sekund og skar sig vej til Columbia-floden på en uge.

Physics Today/JT 